\title{
Sylwia KAROLAK
}

Uniwersytet im. Adama Mickiewicza w Poznaniu

skarolak@amu.edu.pl

\section{UTWORY O MATKACH I CÓRKACH}

\section{KOBIECE NARRACJE POSTMEMORIALNE}

ABSTRACT Stories about Mothers and Daughters. The Feminine Post-memorial Literary Texts

From a large group of Polish postmemory literary texts, the author distinguishes a group that is considered to be significant and separate: Rodzinna historia lęku by Agata Tuszyńska, Utwór o Matce i Ojczyźnie by Bożena Keff, Wtoskie szpilki by Magdalena Tulli oraz Frascati by Ewa Kuryluk. All these works were written by women. There are stories about complicated, often difficult and painful relations between mothers and daughters. It is important that these mothers are Polish Jewesses and Holocaust survivors. Their daughters represent the "second generation". Fathers are absent in the lives of their daughters for many reasons (divorce, death, journey). This absence enables dialogue between the mother and her adult child, which helps shape the identity of the daughter and create the story about the Holocaust experience - the most important caesura and trauma in the mother's life.

Key-words: Shoah, postmemory, second generation, women's stories

Słowa kluczowe: Zagłada, postpamięć, drugie pokolenie, narracje kobiece

\section{WPROWADZENIE}

Literatura polska, w której pojawiają się wątki postpamięciowe dotyczące Zagłady (choć nie tylko i nie wyłącznie), obejmuje już dziś obszerny korpus tekstów ${ }^{1}$. W jego obrębie 
szczególne wydają się te utwory, których autorzy nawiązują do rodzinnych związków z Zagładą. Przedstawiciele tzw. „drugiego pokolenia” przywołują historie swych rodziców, zaś należący do „pokolenia trzeciego” - wojenne przeżycia dziadków. To szczególna grupa tekstów. Na ich osobność, ale i wyjątkowość wskazywało wielu badaczy. Na gruncie polskim, w trakcie spotkania poświęconego Utworowi o Matce i Ojczyźnie, Alina Molisak stwierdzała, że kiedy się mówi o literaturze tzw. drugiego pokolenia, czyli literaturze dzieci ludzi, którzy ocaleli z Zagtady, albo ludzi urodzonych po wojnie, którzy podejmuja tematykę Zagtady, to $w$ literaturze polskiej mamy prezentacje tego tematu, które ja uznatam za dosyć stabe, czyli z jednej strony ksiażkę Marka Bieńczyka „Tworki” i z drugiej strony kilka ksiażek, zaczynajac od "Zagtady”, przez „Zmierzchy i poranki” oraz „Bociany nad powiatem" Piotra Szewca. Te kreacje to rodzaj opowieści z zewnatrz, rodzaj rekonstrukcji $i$ wracania do świata, który byt . Bardziej radykalny jest amerykański pisarz Melvin J. Bukiet, który opowiada się za prymatem i ekskluzywnościa biograficznego charakteru „drugiego pokolenia"s: Chce powiedzieć każdemu, poczynając od Bellowów i Ozicków do Styronów $i$ Wilkomirskich, „Odwalcie się. Znajdźcie sobie swoje wtasne nieszczęścia”, ale nikt nie może być prawodawca artystycznych nakazów i być może nikt nie powinien nim być. Niemniej jednak, jeśli jest to rzeczywiście nasza historia, to mity sq wtasnościa publiczna. Ale nawet jeśli tak jest, to zachowujemy nasze pierwszeństwo. [...] Naszym zadaniem jest opowiadanie historii, krzyczenie „nigdy nie zapomnij!”, pomimo tego, że tam nas nie byto ${ }^{4}$.

Dość nadmienić, że także koncepcja Marianne Hirsch, co sama autorka Family Frames podkreśla, wypracowana została właśnie $w$ odniesieniu do dzieci ocalonych $z$ Zagtady ${ }^{5}$ i dopiero później, niejako wtórnie, uznana za użyteczną do mówienia o pamięci drugiego pokolenia, która dotyczy innych kulturowych czy zbiorowych wydarzeñ i doświadczeñ traumatycznych ${ }^{6}$. Ponadto w swej kolejnej książce The Generation of Postmemory badaczka idzie o krok dalej. Jak słusznie wskazuje Shoshana Ronen, dla Hirsch [...] jest rzecza oczywista, $\dot{z}$ e dyskurs odnoszacy się do „drugiego pokolenia” nie dotyczy tylko biografii potomków pokolenia Szoa, ale również „mniej bezpośrednio dotkniętych uczestników” albo „socjologicznego czy kulturowego, a nawet literackiego drugiego pokolenia jako sktadnika pamięci zbiorowej".

Zagtady. Opolskiej prozie lat 1987-2012, Katowice 2012, Prace Naukowe Uniwersytetu Ślaskiego w Katowicach, nr 3027.

2 Zob.: wypowiedź A. Molisak w trakcie spotkania Wszystko o Matce-Żydówce. Wokót książki Bożeny Keff „Utwór o Matce i Ojczyźnie”, [online] http://genderstudies.pl/index.php/aktualnosci/feminaria/wszystko-o-matce-zydowce-wokol-ksiazki-bozeny-keff-utwor-o-matce-i-ojczyznie-relacja, 25 II 2014.

3 S. Ronen, Od zmagań z bestią nazistowska w piwnicy do zmagań $z$ tą bestią w nas samych, przel. $\mathrm{z}$ ang. S. Obirek, przel. z hebr. M. Sobelman, [w:] Porzucić etyczna arogancje. Ku reinterpretacji podstawowych pojęć humanistyki w świetle wydarzenia Szoa, red. B.A. Polak, T. Polak, Poznań 2011, s. 83.

Tamize, s. 84 .

5 M. Hirsch, Żatoba i postpamięć, przeł. K. Bojarska, [w:] Teoria wiedzy na temat przesztości na tle wspótczesnej humanistyki, red. E. Domańska, Poznań 2010, s. 254.

6 Tamże, s. 254-255.

7 Ronen cytuje kolejno Hirsch i Milner. Zob.: S. Ronen, Od zmagań..., s. 83. Ronen sięga do artykułu Hirsch zamieszczonego w 2008 r. w „Poetics Today”. Tekst ten, w rozszerzonej postaci, przedrukowany 
Każdy z utworów, które poddam analizie w niniejszym szkicu, powstał w oparciu o osobiste doświadczenie kobiet, przynależących biograficznie (a nie wyłącznie w sensie kulturowym i literackim) do „drugiego pokolenia” po Zagładzie. Wszystkie autorki są artystkami, literatkami, zawodowymi pisarkami - ich dzieła nie mają charakteru akcydentalnego. Każda z książek to opowieść przede wszystkim o relacji córek z matkami, ocalałymi Żydówkami (a więc po części także o samej Zagładzie). Ojciec, jeśli się pojawia, jest postacią spoza doświadczenia, jakim było Szoa (nie jest Żydem). Wszystkie historie przełamują tabu - po pierwsze ukazują ocalałego już „po” Wydarzeniu, po drugie relacja niedoszłych ofiar Zagłady z ich bliskimi jest nieprawidłowa lub zaburzona, po trzecie zaś one same nie są osobami o nieskazitelnym charakterze, powiedzieć można, że są zwykłymi ludźmi, mają wady i zalety. Ponadto Zagłada, którą przetrwały, nadal odciska wyraźne piętno na ich życiu; mimo iż rozegrała się w czasie przeszłym, oddziałuje na teraźniejszość. Każda z potomkiń zmagać się musi z prawdą o pochodzeniu swoim i pochodzeniu matki - z nadmiarem opowieści lub jej brakiem. Każda wreszcie doświadcza na własnej skórze, co oznacza bycie Żydówką w Polsce.

Teksty stanowiące przedmiot mojego zainteresowania opublikowane zostały w pierwszej i drugiej dekadzie XX w.: Rodzinna historia lęku w roku 2005, Utwór o Matce i Ojczyźnie trzy lata później, Frascati w 2009 roku, zaś Wtoskie szpilki w roku 2011. Jak wspomniałam, ich autorki są reprezentantkami „drugiego pokolenia”, generacji postpamięci: Ewa Kuryluk urodziła się w roku 1946, Bożena Keff w 1948, Magdalena Tulli w 1955, a Agata Tuszyńska w roku 1957. Powiedzieć można, że prototypem pisania o relacji z ocalałymi z Zagłady bliskimi, pierwowzorem dla interesujących mnie tutaj opowieści, zwłaszcza tych, w których dostrzec możemy destrukcyjny wpływ doświadczeń żydowskiego rodzica na dziecko, jest w literaturze światowej Maus Arta Spiegelmana. Otwarcie o tej inspiracji mówi Bożena Keff ${ }^{8}$, wskazywano na takie powiązania również przy okazji recenzji Utworu o Matce i Ojczyźnie, a także książki Magdaleny Tulli’. Wymienionym wyżej dziełom szczególnie bliskie na gruncie polskim wydają się przede wszystkim książki Romana Grena, urodzonego w 1951 r. - wczesny, bo opublikowany w 1996 r., Krajobraz z dzieckiem oraz późniejsze, pochodzące z roku 2012, Wyznanie. Przeszłość swych bliskich, także w kontekście Zagłady, wspomina również przedstawiciel "trzeciego pokolenia”, autor Pensjonatu wydanego w roku 2010 - Piotr Paziński, rocznik 1973.

został w ostatniej książce Hirsch. Zob.: M. Hirsch, The Generation of Postmemory. Writing and Visual Culture After the Holocaust, New York 2012, s. 33, Gender and Culture.

8 Zob.: K. Bielas, Nielegalny plik, rozmowa z Bożeną Umińską-Keff, „Gazeta Wyborcza” 2008, 27 V, [online] http://wyborcza.pl/duzyformat/1,127291,5250183,Nielegalny_plik.html, 4 III 2014; M. Janion, I. Filipiak, Zmagania z Matka i Ojczyzną, [w:] B. Keff, Utwór o Matce i Ojczyźnie, Kraków 2008, s. 82.

9 Zob.: P. Czapliński, Mausoleum, „Tygodnik Powszechny” 2008, nr 37, [online] http://tygodnik. onet.pl/kultura/mausoleum/8fsvl, 27 II 2014; M. Zaleski, „Wtoskie szpilki” Magdalena Tulli, [online] http://www.instytutksiazki.pl/ksiazki-detal,literatura-polska,3169,wloskie-szpilki.html, 26 II 2014. 


\section{SCENY (POST)PAMIĘCI, HISTORIE RODZINNE, NARRACJE KOBIECE}

O historiach i narracjach rodzinnych pisano w kontekście literatury tworzonej przez kobiety, także literatury współczesnej ${ }^{10}$. Analizie poddane zostało również kobiece doświadczenie wojny i Zagłady ${ }^{11}$. Autobiografizm natomiast uznaje się za jeden z wyznaczników kobiecego pisarstwa ${ }^{12}$. O swych biografiach, które legły u podstaw interesujących nas tutaj utworów, pisarki opowiadały w wywiadach ${ }^{13}$. Także w recenzjach podkreślano autobiograficzność dzieł Keff, Tulli, Kuryluk i Tuszyńskiej ${ }^{14}$. W przypadku Utworu o Matce i Ojczyźnie wskazywano na „silne uwikłanie w biografię”15, w kontekście Wtoskich szpilek pisano o „zakamuflowanej autobiografii”"16, we Frascati widzia-

10 A. Galant, Zakochane bez pamięci. Szkic do wspótczesnych kobiecych „narracji rodzinnych”, [w:] Poetologie pamięci, red. D. Śnieżka, Szczecin 2011, s. 261-284, Rozprawy i Studia - Uniwersytet Szczeciński, t. 806; T. Czerska, Historia rodziny - rodzina w historii, [w:] Prywatne/publiczne. Gatunki pisarstwa kobiecego, red. I. Iwasiów, Szczecin 2008, s. 193-232, Rozprawy i Studia - Uniwersytet Szczeciński, t. 723. Zob. także: M. Brzóstowicz, Wizerunek rodziny w polskiej prozie wspótczesnej, Poznań 1998, Biblioteka Literacka „Poznańskich Studiów Polonistycznych”, t. 8.

11 Wymienię tylko najważniejsze prace: D. Dąbrowska, Udomowiony świat. O kobiecym doświadczaniu historii, Szczecin 2004, Rozprawy i Studia - Uniwersytet Szczeciński, t. 512; A. Ubertowska, „Niewidzialne świadectwa”. Perspektywa feministyczna w badaniach nad literatura Holokaustu, „Teksty Drugie" 2009, nr 4, s. 214-226; A. Nikliborc, Uwięzione w KL Auschwitz-Birkenau. Traumatyczne doświadczenia kobiet odzwierciedlone w dokumentach osobistych, Kraków 2010; J. Stöcker-Sobelman, Kobiety Holokaustu. Feministyczna perspektywa w badaniach nad Shoah. Kazus KL Auschwitz-Birkenau, Warszawa 2012; B. Karwowska, Ciato. Seksualność. Obozy zagtady, Kraków 2009, Modernizm w Polsce, t. 28; P. Czapliński, Wypowiadanie wojny. Literatura najnowsza wobec okresu 1939-1945, [w:] Wojna i postpamięć, red. Z. Majchrowski, W. Owczarski, Gdańsk 2011, s. 417-439.

12 Zob.: A. Ubertowska, Archeologie pamięci. Wspótczesne kobiece narracje o wojnie, [w:] Wojna i postpamięć, s. 187-198.

13 Zob. np. rozmowy z E. Kuryluk: E. Winnicka, Kangur w skórze stonia. Rozmowa z Ewa Kuryluk. O powojennym dzieciństwie, traumach, chorobie i wytchnieniu, które daje sztuka, „Polityka” 2010, 27 III, [online] http://www.polityka.pl/tygodnikpolityka/kultura/1504420,1,rozmowa-z-ewa-kuryluk.read, 3 III 2014; M. Wilk, Życie jako dzieto sztuki, „Polityka” 2009, 13 X, [online] http:// www.polityka.pl/tygodnikpolityka/kultura/304502,1,zycie-jako-dzielo-sztuki.read, 15 IV 2014; rozmowę z M. Tulli: K. Kubisiowska, Magdalena Tulli: Ludzik mi padt, więc gram następnym, „Gazeta Wyborcza” 2011, 30 X, [online] http://wyborcza.pl/duzyformat/1,127291,10548289,Magdalena_Tulli_Ludzik_mi_padl_wiec_gram_nastepnym.html, 15 IV 2014; rozmowę z B. Keff: K. Bielas, Nielegalny plik.

14 Zob. np.: G. Wysocki, Magdalena Tulli, „Wtoskie szpilki”, dwutygodnik.com, [online] http://www. dwutygodnik.com/artykul/2862-magdalena-tulli-wloskie-szpilki.html, 15 IV 2014.

15 A. Choduń, Córka o matce, czyli „potwór” Bożeny Keff, „Tygiel Kultury” 2011, nr 7-9, [online] http:// www.tygielkultury.eu/7_9_2011/aktual/30.htm, 4 III 2014.

16 T. Sobolewski, Nike 2012. Magdalena Tulli: nie ma zmyślonych opowieści, „Gazeta Wyborcza” 2012, 15 IX, [online] http://wyborcza.pl/1,75475,12487543,Nike_2012_Magdalena_Tulli_Nie_ma_ zmyslonych_opowiesci.html, 4 III 2014. 
no opowieść o „tajemnicach, rodzinnych tabu”" zaś Rodzinną historię lęku określano mianem „pierwszej polskiej autobiografii drugopokoleniowej” 18 .

Portrety rodzin oraz poszczególnych ich członków bez trudu odnaleźć można w literaturze polskiej podejmującej temat Zagłady. Myślę tutaj o tej jej części, która oparta jest na pamięci, na doświadczeniu bezpośrednim, przede wszystkim doświadczeniu ofiar (ale i świadków), by przywołać choćby Chleb rzucony umartym Bogdana Wojdowskiego, Żydowska wojnę Henryka Grynberga, Czarny potok Leopolda Buczkowskiego, Czarne sezony Michała Głowińskiego; zaś na gruncie poezji na przykład Pamiętnik mitości Stanisława Wygodzkiego, czy Dzieci getta Stefanii Ney. Lista jest długa, zaś problem zasługuje na osobne potraktowanie. Szczególną grupę tekstów, po części tylko pokrywającą się z poprzednią, stanowią te, które poświęcone zostały wojennym losom dzieci żydowskich ${ }^{19}$.

Lawrence Langer w odniesieniu do wydarzeń Zagłady pisał: Wśród wielu zbrodni, jakich dopuścity się wobec swoich ofiar hitlerowskie Niemcy, jedna z najpoważniejszych byto zerwanie więzi rodzinnych ${ }^{20}$, zaś swe rozważania kończył spostrzeżeniem: Więź między rodzicami i dziećmi $w$ takich i $w$ tysiacach innych, podobnych rodzin, które [...] [mają] stratę do optakania, jest bardzo ztożona ${ }^{21}$. O ile Langer w swym szkicu analizuje wyłącznie świadectwa odnoszące się do czasu Zagłady, to dostrzega w konkluzji, że spostrzeżenia odnośnie do destrukcyjnego wpływu Szoa na kondycję rodziny odnoszą się z powodzeniem także do dekad powojennych.

Psychiatrzy natomiast wyróżniają sześć kategorii służących do opisu rodzin zakładanych przez ocalałych z Zagłady: rodziny ofiar (victim families), rodziny bojowników (fighter families), rodziny wycofane (numb families), rodziny „tych, którzy tego dokonali” (families of „those who made it"), rodziny „życie idzie dalej” („life goes on” families) oraz rodziny rozszczepione (split families) 22 . Nie chcę w tym miejscu wpisywać rodzin przedstawionych na kartach interesujących mnie utworów w żaden $\mathrm{z}$ wymienionych modeli. Ciekawe poznawczo wydaje mi się natomiast przedstawienie pewnych ich cech,

17 J. Strzałka, Sekrety rodzinne. Recenzja ksiażki: Ewa Kuryluk, „Frascati”, „Polityka” 2009, 13 X, [online] http://www.polityka.pl/tygodnikpolityka/kultura/ksiazki/304410,1,recenzja-ksiazki-ewa-kuryluk-frascati.read, 4 III 2014.

18 T. Łysak, Meandry ujawniania - póżne odkrycie tożsamości w „Rodzinnej historii lęku” Agaty Tuszyńskiej, [w:] Zagtada. Wspótczesne problemy rozumienia i przedstawiania, red. E. Domańska, P. Czapliński, Poznań 2009, s. 195, Biblioteka Literacka „Poznańskich Studiów Polonistycznych”, t. 56.

19 O obrazach śmierci żydowskiego dziecka w zapisach polskiej literatury o Zagładzie mówiłam w trakcie seminarium „Zabójstwo dziecka w literaturze i kulturze europejskiej”, które w dniach 13-15 grudnia 2013 r. odbyło się w Poznaniu. Zob.: S. Karolak, Zabójstwo dziecka w literaturze polskiej o Zagtadzie, [w:] Zabójstwo dziecka w literaturze i kulturze europejskiej, red. nauk. K. Ilski i in., Poznań 2014, s. 163-179, Badania Interdyscyplinarne - Uniwersytet im. Adama Mickiewicza w Poznaniu, nr 36.

20 L. Langer, Scena pamięci. Rodzice i dzieci w tekstach i świadectwach Holokaustu, przeł. J. Mikos, „Literatura na Świecie" 2004, nr 1/2, s. 127.

21 Tamże, s. 139.

22 Przywołuję tutaj ustalenia i wyniki badań Katarzyny Prot-Klinger, Wptyw traumy na relacje $w$ rodzinie, [w:] taż, Życie po Zagtadzie. Skutki traumy u ocalatych z Holocaustu. Świadectwa z Polski i Rumunii, Warszawa 2009, s. 83-84, Monografie Psychiatryczne, 9. 
które jak sądzę, zdają się opisywać (niewyczerpująco) relacje rodzinne (a właściwie: relacje między matkami a córkami) poddawane analizie w niniejszym szkicu. I tak: w rodzinach ofiar somatyzacja stanowi nieświadoma ekspresję żatoby i ztości, sprzyja także kontroli i manipulowaniu wśród cztonków rodziny ${ }^{23}$, podobnie jak w rodzinach bojowników nadopiekuńczość dzieci wobec rodziców i nadmierne wtączanie się rodziców w życie dzieci ogranicza ich relacje $z$ osobami spoza rodziny ${ }^{24}$; w rodzinach wycofanych $d z i e c i$ nie wierza, że inni moga uznać ich za wartych uwagi ${ }^{25}$; natomiast w rodzinach "tych, którzy tego dokonali" dominuje strategia zaprzeczania - czessto przesztość jest ukrywana przed dziémi, bądz komunikowana nie wprost ${ }^{26}$. Ponadto, o czym wspomina Katarzyna Prot-Klinger, omawiając charakterystykę rodzin rozszczepionych, matki ocalone z Holocaustu przekazuja w rodzinach raczej model ofiary, gdy ojcowie prezentuja postawe identyfikacji z bojownikiem, natomiast w sytuacji, gdy matki mówią o swoich doświadczeniach, dzieci (szczególnie córki) poprzez identyfikacje, widza siebie także $w$ roli ofiary ${ }^{27}$. Zasadne wydaje się zatem podkreślenie, że nie treść przekazu, a jego sposób, „narracja” rodziców, wptywa na adaptacje drugiego pokolenia ${ }^{28}$.

W historii, którą opowiada Bożena Keff ${ }^{29}$, ojciec zostawiony zostaje poza nawiasem - jak mówią w duecie Narratorka i Usia - nie dlatego nie ma na obrazku Ojców, I że być nie powinno. Powinno, bez dyskusji. [...] Ale taki jest nasz przypadek ${ }^{30}$. Ojciec-mężczyzna przedstawiony zostaje stereotypowo: jako powołany do innych, być może wyższych celów niż „zwykłe”, rodzinne życie, ale także jako ten, który rodzinę opuszcza, kto odchodzi do świata rywalizacji, władzy, folgowania ciału i zmysłom. W schemacie tym dziecko zostaje z matką, bo „nie ma jak Matka”.

Z kolei we Wtoskich szpilkach ojciec, Włoch z pochodzenia, zostawia córkę samej sobie $e^{31}$ - mimo że często jest w domu, nie poświęca dziecku uwagi, nie dostrzega jego samotności, opuszczenia, braku matczynej miłości. Wydaje się funkcjonować wyłącznie na linii Warszawa-Mediolan, mentalnie pozostaje nieustannie poza domem, z dala od jego spraw: ojciec niemowlęcia, przystojny cudzoziemiec zza żelaznej kurtyny, [...] pochwalat idee wychowania bez rozpieszczania, w zdrowym chtodzie. Poza tym troche się brzydzit: niemowlęta są zawsze zaślinione, zawsze roztaczaja specyficzny zapaszek. $W$ jego rodzinie matymi dziećmi zajmowaty się niańki ${ }^{2}$.

23 Tamże, s. 83.

24 Tamże, s. 83-84.

25 Tamże, s. 84.

26 Tamże.

27 Tamże.

28 Tamże.

29 Ojciec Bożeny Keff, o czym mówi sama pisarka i na co wskazują recenzenci, np. cytowana uprzednio A. Choduń, popełnił samobójstwo, gdy jego córka miała sześć lat.

30 B. Keff, Utwór o Matce i Ojczyźnie, s. 68. Dalej oznaczam w tekście głównym UoMiO i podaję numer strony.

31 M. Zaleski, „Wtoskie szpilki”...

32 M. Tulli, Wtoskie szpilki, Warszawa 2011, s. 13. Dalej cytaty oznaczam w tekście głównym $W_{s z}$. i podaję numer strony. 
W świetle tym bardzo szczegółowe wydają się portrety ojców nakreślone przez Ewę Kuryluk i Agatę Tuszyńską, choć główną cechą ojca tej ostatniej jest właśnie ciągła nieobecność. Bogdan Tuszyński z racji wykonywanego zawodu często przebywał poza domem. Był dla córki przybyszem z dalekiego, lepszego świata - tatą, z którego mogła być dumna, gdy słyszała jego głos w radiu. Długo myślała, że rozstanie rodziców nastąpiło $\mathrm{z}$ winy ojca, nie przypuszczała, że mogła to być decyzja matki, która zakochała się w innym mężczyźnie. Jak przyznaje Tuszyńska, mówić można o co najmniej niechętnym stosunku jej ojca do Żydów. W Rodzinnej historii lęku czytamy: Matka samotna, oparta o mnie i o moje życie. Ojciec otoczony druga rodzina, z dwiema wnuczkami, po jednej od każdej z córek, i planami następnych książek o historii sportu. Nie ustaje w wysitku tworzenia. Jak zawsze gtośno krzyczy, na rząd, na prawice, na lewice, na Kościót, na Żydów ${ }^{33}$.

Natomiast Karol Kuryluk, zwany Łapką, pojawia się na kartach Frascati. Apoteozy topografii, utworu programowo poświęconego i dedykowanego jego żonie ${ }^{34}$. Jest ostoją rodziny, nauczycielem wartości, źródłem spokoju. Nie tylko odnosi sukcesy zawodowe, ale doskonale zajmuje się rodziną, trzyma ją w ryzach, zwłaszcza w trakcie nawrotów choroby psychicznej żony. Dla córki stanowi wzór do naśladowania. Jak się później okaże, jest przy tym bohaterem - w czasie wojny ratował lwowskich Żydów, za co odznaczony został medalem „Sprawiedliwy wśród Narodów Świata”. Jedną z tych, którym Karol Kuryluk udzielił pomocy, była Miriam Kohany, jego późniejsza żona, matka Ewy i Piotra. Przedwczesna śmierć Łapki jest wielkim ciosem przede wszystkim dla córki, która na swe barki przyjąć musi odtąd ciężar opieki nad matką i bratem. To właśnie ojciec nauczył Ewę Kuryluk, że w obliczu choroby matki musi zachować się dzielnie, że nie może uciec: Przysiegtam Łapce tamtej nocy. I stąd, choć nieraz brakowato mi kurażu, przychodzitam w końcu po rozum do gtowy ze strachu, żeby nie przepoczwarzyćsię w tchórza. Gdybym nim zostata, nie dowiedziatabym sięnigdy, jak dzielnym cztowiekiem okaże się mama ${ }^{35}$.

W sytuacji, gdy nie ma ojca (praca zawodowa, wyjazdy, rozwód, samobójstwo, śmierć), jedynym rodzicem pozostaje naznaczona traumatycznym doświadczeniem z przeszłości matka, co istotne szczególnie w kontekście polskim: matka-Żydówka. Bagaż, którym jest obciążona, nie umyka czujnym, dziecięcym oczom. Bohaterki analizowanych w tym szkicu utworów przypominają sobie, że już w dzieciństwie odbierały sygnały, które wskazywały nie tylko na żydowskie pochodzenie ich matek, ale także na fakt, że są jednymi z ocalałych, że przeżyły Zagładę. Córki stają się spadkobierczyniami rodowodu, innego niż rodowód ojca ${ }^{36}$, a tym samym spadkobierczyniami traumy, ściśle z żydowskim rodowodem związanej.

A. Tuszyńska, Rodzinna historia lęku, Kraków 2005, s. 40-41. Dalej cytaty oznaczam w tekście głównym $R b l$. i podaję numer strony.

34 Kuryluk mówi: $W$ „Goldim” mama byta marginesowa, chciatam jej oddać gtos - D. Jarecka, Ewa Kuryluk: kazdy jest dla kogoś dobry, "Gazeta Wyborcza” 2010, 6 X, [online] http://wyborcza. pl/1,75475,7112897,Ewa_Kuryluk_Ktos_jest_dla_kogos_dobry.html, 27 II 2014.

35 E. Kuryluk, Frascati. Apoteoza topografii, Kraków 2009, s. 123. Dalej cytaty oznaczam w tekście głównym $F r$ i i podaję numer strony.

36 Tylko ojciec Bożeny Keff był z pochodzenia Żydem. Wzmianka o tym nie pojawia się na kartach Utworu o Matce i Ojczyźnie. Pisarka mówi o pochodzeniu rodziców w wywiadach. 


\section{UTWORY O MATKACH I CÓRKACH}

Do postaci matek odsyłają już tytuły analizowanych w niniejszym szkicu utworów: bezpośrednio, jak w Utworze o Matce i Ojczyźnie, lub pośrednio. I tak: ulica Frascati i zlokalizowane tam mieszkanie, zwane „małą Italią,, to miejsce ukochane przez Marię Kuryluk, z którego nie chciała wyprowadzić się do przestronnej willi. To skarbiec rodzinnych pamiątek, których nie sposób przejrzeć, a także, przed wszystkim, miejsce, w którym znajdują się klucze do tajemnicy pochodzenia i wojennego losu matki Ewy Kuryluk. „Rodzinny lęk”, którego historię opowiada Agata Tuszyńska, związany jest bezpośrednio z żydowskim pochodzeniem matki. Chodzi bowiem o to, by nikt żydowskości nie odkrył; to paradoksalnie lęk przed życiem w strachu, które trzeba będzie wieść po tym, gdy prawda wyjdzie na jaw. Atrybutem matki są także tytułowe włoskie szpilki. Córka zna doskonale ubrania rodzicielki oraz jej buty - nie może natomiast w żaden sposób zbliżyć się do ich właścicielki. Dziewczynka rozpoznaje charakterystyczny stukot matczynych obcasów, podziwia lekkość i grację, z jaką się porusza. Tak samo dźwięczały obcasy, gdy matka szła do pracy, w której spędzała całe dnie, uwolniona od córki; tak samo brzmiały, gdy podchodziła do córki, by wymierzyć jej siarczysty policzek.

We wszystkich analizowanych tekstach córki zabierają głos po osiągnięciu pełnej dojrzałości i jedynie w retrospekcjach przywołują własne dzieciństwo - wydarzenia przedstawiane są wówczas najczęściej z perspektywy dziecka. Natomiast matki są już wówczas osobami w podeszłym wieku. Wspominają młodość świadomie (Frascati) lub na skutek choroby (Wtoskie szpilki). Wedle Halbwachsa zachodzące w rodzinie nieuchronne przemiany: wypadki śmierci, narodziny, choroby, nadchodzaca starość, zwolnienie czy rozwój indywidualnej aktywności organicznej jej cztonków - wszystko to stopniowo modyfikuje jej wewnętrzna strukturę ${ }^{37}$, zaś ewolucja ta dostrzegana jest przez tych członków rodziny, którzy nie izolują się całkowicie od świata zewnętrznego, nie zamykają się w rodzinnych ramach. Dorosłe już córki z własnej woli lub wskutek życiowej konieczności spędzają ze swymi matkami dużo czasu. Zasadne wydaje się tutaj odwołanie do koncepcji Virginii Woolf, sformułowanej we Wtasnym pokoju, i nieznaczna jej modyfikacja. Wydaje się bowiem, że rozmowy w obrębie kobiecej wspólnoty, rozmowy kobiet z kobietami, dzielącymi „wspólny pokój”, stwarzającymi wspólną przestrzeń - koegzystencji, dialogu, pozwalają na dotarcie do wydarzeń z przeszłości, dotychczas dla młodszej z kobiet niedostępnych, a także - stworzenie więzi. Ale postpamięć oparta jest nie tylko na pamięci rodziny, na obecnych w niej narracjach. Konieczność wyjścia poza rodzinne ramy pojawia się przede wszystkim wówczas, gdy wspomniane narracje mają charakter szczątkowy, gdy pełne są białych plam, luk, które domagają się uzupełnień. Córki sięgają zatem do tego, co pozostaje w ich zasięgu: do opowieści bliskich - przyjaciół, innych członków rodziny, do ksiąg metrykalnych, rodzinnych zbiorów zdjęć, pro-

37 M. Halbwachs, Zbiorowa pamięć rodziny, [w:] tenże, Spoteczne ramy pamięci, przeł. i wstęp M. Król, Warszawa 1969, s. 248, Biblioteka Socjologiczna. 
szą o pomoc historyków, wyjeżdżają do miejsc, w których rozgrywały się dramatyczne, dotyczące Zagłady, doświadczenia ich matek - kupują przewodniki turystyczne, aktualne i stare plany miast, zachowują się jak detektywi. To córki poszukują sposobu, by opowiedzieć o życiu matek, a więc także: by opowiedzieć o Zagładzie. Jak czytamy w Zbiorowej pamięci rodziny: Najczęściej ci spośród nich, którzy nie catkiem izolują się od innych spoteczeństw rodzinnych i od otaczającego spoteczeństwa w ogóle, stwierdzaja, że ich rodzice juz nie sa dzisiaj tacy jak dawniej, poprawiaja więc i uzupetniaja zbiór wspomnień rodzinnych, przeciwstawiając niepewnym stowom starzejących sięświadków opinie ludzi z innych rodzin, a także analogie, pojęcia bieżace oraz zespót idei przyjętych wich czasach, poza ich grupa, ale wokót niej. Tak oto historia nie ogranicza się do odtwarzania opowieści ludzi wspótczesnych minionym wydarzeniom, ale z epoki na epokę retuszuje je, nie tylko dlatego, że dysponuje innymi świadectwami, ale ipo to, by przystosować te opowieści do sposobów myślenia i przedstawić sobie przesztość ludzi teraźniejszych ${ }^{38}$.

W badaniach psychiatrycznych mówi się o międzygeneracyjnym przekazie traumy, na który składają się: zmowa milczenia z towarzyszącym jej fenomenem „podwójnej ściany” (Rodzice nie mówią, a dzieci nie pytają. Jeżeli ktoś otworzy okno po swojej stronie, to $z$ reguty napotyka ściane po drugiej ${ }^{39}$ ); niewerbalna komunikacja pomiędzy nowonarodzonym dzieckiem i ocalata $z$ Holocaustu matka ${ }^{40}$ - dziecko wyczuwa i niejako „wchłania” smutek rodzicielki, jej zatroskanie, deficyt uczuć, stan ciągłego napięcia. Wedle tych ustaleń „drugie pokolenie” absorbuje nie tylko emocje, ale także traumatyczne treści - opisuje doświadczenia wojenne rodziców tak, jakby w nich uczestniczyto, pomimo świadomych dążen rodziców do nieobciążania ich ta wiedzą $q^{41}$; pojawia się zjawisko transpozycji, czyli żatoby po obiektach, które nie zostaty bezpośrednio utracone przez żatobnika (na przyktad rodzina, która zginęta przed narodzeniem osoby $z$ „drugiego pokolenia”), powodującej życie w dwóch wymiarach czasowych - przeszłości i teraźniejszości. Wskutek odwrócenia procesu identyfikacji projekcyjnej dzieci staja siękontenerem na niemożliwe do pomieszczenia uczucia rodziców - żatoby i agresji $i^{42}$.

Świadectwa tych konsekwencji urazu rodziców, w tym wypadku matek, odnajdujemy w analizowanych tekstach ${ }^{43}$. Na milczeniu opiera się powojenna egzystencja bohaterek Wtoskich szpilek, Rodzinnej historii lęku oraz Frascati. Jak pisze Magdalena Tulli, o pożarze, po którym wydarzyto się to wszystko, wiedziatam. Wszędzie oprócz naszego domu o nim się mówito ( $W_{s z .}$, s. 31), zaś matka rozumiata, że trzeba zachowywać się,

\section{Tamże, s. 249.}

39 K. Prot-Klinger, Wptyw traumy..., s. 85.

40 Tamże.

41 Tamże, s. 87.

42 Tamże, s. 88.

43 Matka Ewy Kuryluk mówi wprost: Uraz jest jak tabu [...] przechodzi z matki na dziecko, z pokolenia na pokolenie. [...] Ale to nie może trwać wiecznie [...] nikt nie chce siedziećpod podtoga do zgonu (Fr., s. 136). Wspomina także i pyta: „Meine Kleinen” też to miaty [empatię - S.K.], ale nie w takim stopniu. Czy dzieci ofiar utożsamiaty się odruchowo $z$ ofiarami? (Fr., s. 113). Znaczące, że w początkowych partiach $F r$., niedobitkiem Maria Kuryluk nazywa siebie (Fr., s. 11), później mianem tym określi siebie i syna (Fr., s. 27), następnie siebie i córkę (Fr., s. 315). 
jakby nigdy nie byto żadnej przesztości ( $W_{s z}$. s. 25). Agata Tuszyńska stwierdza, że matka nie chciata zrzucać dziecku na barki ciężaru, którego nie będzie w stanie udżwignać. Nie chciata, żeby jej córka rosta w lęku i poczuciu krzywdy. Sądzita, ze można poruszyć ten temat, kiedy będzie mogta to unieść i ewentualnie się bronić (Rhl., s. 10). Ani Halina Przedborska-Tuszyńska, ani Agata Tuszyńska nie pamiętają okoliczności czy sposobu, w jaki przekazana została prawda o wojennym losie tej pierwszej, a zarazem - pochodzeniu obydwu kobiet. Skądinąd wiadomo, że autorka Rodzinnej historii lęku miała wówczas 19 lat. Natomiast matka Ewy Kuryluk wymogła na niej obietnicę, że do końca jej życia córka nie będzie rozgtaszać naszej historii ani szukać śladów (Fr., s. 237). Był rok 1985. Prośba Marii Kuryluk była konsekwencją twierdzącej odpowiedzi na pytanie zadane jej przez córkę: Czy jesteś...? (Fr., s. 237).

Zupełnie inaczej przedstawia się sytuacja w Utworze o Matce i Ojczyźnie. Tutaj matka mówi o swoim doświadczeniu nieustannie. Jak piszą Maria Janion i Izabela Filipiak, narracja matki służy podkreśleniu zarówno jej prawa do życia, jak i związku z rodziną, która zginęła. W układzie tym nie ma miejsca dla córki, która $z$ Niczym nie ma Niczego wspólnego. Osaczona Usia próbuje uciec od zawłaszczającej opowieści. Jednak aby utrzymać córkę w gotowości do stuchania, matka grozi samobójstwem [...] Życzy sobie, by córka byta "moim mężem, moja matka-ojcem" i umacnia w niej poczucie winy: "bo to byto dla ciebie, przez ciebie, z twojego powodu" "'. Córkę urodziła, aby mieć rodzine, aby nie być sama, by zyskać jakaśs tożsamość (UoMiO, s. 10).

Także we Wtoskich szpilkach posiadanie dziecka było dla matki legitymizacją istnienia w teraźniejszości i przyszłości. Jednak, jak wskazuje Tulli, i tutaj transakcja była wiązana, gdyż ta, która dała życie, oczekiwata pomocy. Dziecko powinno byto zrozumié, że to ona na cośliczy, że czegośpotrzebuje iże jej się to należy ( $W_{s z}$., s. 27). Ceną, jaką zmuszona była zapłacić córka, była egzystencja w cieniu doświadczenia matki, po którym $w$ niej samej cośsptonęto i zgasto (Wsz., s. 30). Jak pisze Tadeusz Sobolewski, prócz balansowania między Mediolanem a Warszawą jest jeszcze jedna granica, która narratorka „Wtoskich szpilek" musi nieustannie przekraczać - matka nienależaca do żadnego $z$ dwóch światów. Sama byta "tym trzecim, odciętym, niedostępnym" swiatem. Wypalonym po obozie $e^{45}$.

Maria Kuryluk obawia się tajemniczych innych - tych, którzy mordują (Fr., s. 5), Gestapo dostrzega także podczas wakacji, na jednym ze statków (Fr., s. 24), zapomina o swoich dzieciach ( $F$ r., s. 6), które chodzą brudne ( $F$ r., s. 24), podobnie zresztą jak ona sama ( $F r$., s. 6), wspomina o śladach wojny w psychice ( $F r$. s. 113), wreszcie mówi: Po śmierci Teddy'ego pomieszato mi się w gtowie (Fr., s. 158). Ewa Kuryluk w wywiadzie udzielonym już po śmierci matki wspomina: Nic nie wskazuje na to, że przed wojna mama chorowata psychicznie. [...] Wydaje mi się, że choroba wybuchta u mamy na skutek przeżyć wojennych i powojennych - pogromów w Krakowie i Kielcach. No i zagadkowego zgonu jej pierwszego męża Teddy'ego Gleicha [...] Mama bata się panicznie o mnie i Piotrusia. Może ukrywata się, by i nas ukryć? Ukrywata się do śmierci 1 stycznia 2001 roku ${ }^{46}$.

\footnotetext{
44 M. Janion, I. Filipiak, Zmagania..., s. 85.

45 T. Sobolewski, Nike 2012. Magdalena Tulli...

46

E. Winnicka, Kangur w skórze stonia...
} 
Według Ewy Kuryluk to jej brat najsilniej odczuł konsekwencje wojennej traumy matki, jak mówi: zagtadę Żydów wziąt sobie do serca bardziej niż ja ${ }^{47}$. Choroba Miriam Kohany, jej depresja i schizofrenia, wpływały na życie całej rodziny. Wywoływały bunt nastolatki, która nazywała matkę cholerną, starq wariatkq (Fr., s. 121, 154, 199, 200, 202, 203). Ta zaś groziła synkowi pięścią, a córce pokazywała język (Fr., s. 203). Narratorka Utworu o Matce i Ojczyźnie nazywa matkę „tyranicą pustki”, „kretynką,, „hieną”, jej mowę określa natomiast jako „szczekanie”, zaś swą reakcję na zachowanie matki streszcza w stwierdzeniu: „pocałuj mnie w dupe”.

Autorki interesujących w kontekście niniejszych rozważań utworów podjęły się zatem iście karkołomnego zadania: nie tylko opisały relację z matką, nie tylko przedstawiły często wstydliwe sekrety rodzinne, powiedzieć można „prywatne sprawy”, które nie powinny ujrzeć światła dziennego, ale także, co najważniejsze - ukazały ocalałe z Zagłady matki w ich pozagładowej codzienności, w życiu „po”, w życiu naznaczonym piętnem Zagłady, która już się dokonała. Warto podkreślić w tym miejscu, że Kuryluk opublikowała Frascati, zaś Tulli Wtoskie szpilki już po śmierci najbliższych. Inaczej było w przypadku Agaty Tuszyńskiej i Bożeny Keff. Maria Janion i Izabela Filipiak podkreślały, iż opisanie matki przez córkę to zadanie ryzykowne (jeśli zdradzimy matkę, to kto nam zostanie?) i spotecznie mato aprobowane (konsensus spoteczny mówi, że matkę trzeba szanować), a wreszcie obrazoburcze. Tym bardziej że matka $z$ „Utworu o Matce i Ojczyźnie” jest polska Żydówka, która jako jedyna z catej rodziny przeżyta Holokaust. Jest nosicielka tragedii prywatnej, a także tragedii swojego narodu ${ }^{48}$. Matka jest zatem ofiarą, tą, która ocalała. Joanna Ostrowska stwierdzała, że dla dyskursu poholokaustowego pojęcie ofiary jest pojęciem kluczowym oraz że dyskurs przesztości jest wytwarzany pod kontrola strażników zbiorowej pamięci, zaś pamięć oddana w ręce pokrzywdzonych mode-

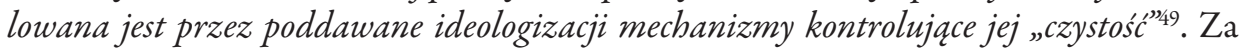
Raulem Hilbergiem wskazywała na hierarchizację ocalałych w zależności od stopnia ryzyka i rozmiaru cierpienia, które przypadły im w udziale, a także podkreślała istnienie zjawiska tabuizacji i stygmatyzacji pewnych grup ofiar, które nie wpisuja się w powszechnie obowiazujaca hierarchie ocalatych ${ }^{50}$. Ponadto Ostrowska, na przykładzie dialogu Hanny Krall i Marka Edelmana, zamieszczonego w Zdązyć przed Panem Bogiem, zwracała uwagę na kształt społecznych oczekiwań, dotyczących tego, kto może być ofiarą, jaki powinien być ktoś, kogo określać można tym mianem ${ }^{51}$. Na trudności pojawiające się w sytuacji, gdy chcemy podjąć się oceny pewnych postaw i zachowań ofiar,

Tamże. Piotr Kuryluk, brat Ewy, podobnie jak ich matka cierpiał na chorobę psychiczną.

48

49

J. Ostrowska, Obca ofiara - figura prostytutki obozowej i jej wyparcie $w$ dyskursie poholokaustowym, „uniGENDER” 2010, nr 1, [online] www.unigender.org/?page=biezacy\&issue=04\&article=02, 2 II 2014. Tekst w zmienionej formie ukazał się także w tomie: Auschwitz i Holocaust. Dylematy i wyzwania polskiej edukacji, red. P. Trojański, Oświęcim 2008, s. 285-292.

50

$51 \quad$ - Czy zreszta wypada pisać, że w getcie byty prostytutki? - Nie wiem. Pewnie nie. W getcie powinni być męczennicy i Joanny d'Arc, prawda? - tamże. 
wskazywał cytowany uprzednio Langer ${ }^{52}$. W odniesieniu do złożoności relacji między ocalałymi rodzicami a ich urodzonymi po wojnie dziećmi konkludował: Najlepszym wyrazem hotdu, jaki możemy im ztożyć, to wyobrazić sobie, jak wielkie znaczenie w ich pamięci ma stres związany z nieobecnościa zmartych - nigdy niekończąca się walka o to, by odzyskać jakiś fragment tamtego utraconego życia ${ }^{53}$. Przemysław Czapliński natomiast pytat: Czy niedoszta ofiara Holokaustu może okazać się cztowiekiem ztym? Podtym? Czy może być rasistą? Źle wychowywać swoje dzieci? Znęcać się nad nimi psychicznie?, i udzielał prostej, acz trudnej odpowiedzi: Życie podpowiada, że tak $k^{54}$.

W analizowanych tekstach pojawia się nowe spojrzenie na ofiarę. To spojrzenie postpamięciowe - niedoszła ofiara Zagłady nie jest ukazana w sytuacji granicznej, jej życie nie jest bezpośrednio zagrożone. Widzimy ją w oderwaniu od doświadczenia, które nadało jej status ofiary - w interakcjach z najbliższymi. Dostrzegamy ponadto, jak bardzo jest ludzka, niedoskonała. Oczom czytelnika ukazane zostają jej choroby, niedomagania wynikające ze starości, wreszcie: jej fizjologia. Rozumiemy, że córka ma dość matki, która znęca się nad nią psychicznie, że nie potrafi znieść matki-schizofreniczki, matki-agresora. W takiej matce nie widzimy ofiary. Następuje znaczące, kluczowe przesunięcie: jeśli to córka staje się ofiarą tej, która dała jej życie, to kim jest matka?

\section{WIĘŹNIARKI PIEKIELNEJ PLANETY}

W Mausie, stanowiącym, jak wspomniałam, pierwowzór literackiego przedstawienia skomplikowanych relacji między ocalałym z Zagłady rodzicem a jego potomkiem, to między ojcem a synem rozgrywa się główna oś dramatycznego napięcia. Andzia Spiegelman popełniła samobójstwo w 1968 r. Podobnie jak matka Ewy Kuryluk zmagała się z zaburzeniami psychicznymi. Już przed wojną walczyła z depresją. Doświadczenia wojenne: pobyt w getcie i w KL Auschwitz-Birkenau, ukrywanie się, permanentny strach, a także śmierć synka i niemal całej rodziny pogorszyły tylko jej stan. Tom pierwszy Mausa dedykowany jej właśnie matce autora. W jego obręb włączony został Więzień piekielnej planety, bardzo osobisty komiks, narysowany przez Spiegelmana w następstwie samobójczej śmierci jego matki. Syn tyleż próbuje określić możliwe przyczyny, dla których Andzia targnęła się na swoje życie: KLIMAKTERIUM! DEPRESJA! HITLER TO ZROBIE! MAMUSIU! SUKA ${ }^{55}$, co oskarża: A więc, mamo, jeśli mnie styszysz... Gratulacje! Popetnitaś zbrodnię doskonata... wepchnętaś mnie tutaj... zrobitaś

52 Badacz, analizując dzienniki, notatki oraz wspomnienia ofiar, stwierdzał, iż w obliczu dramatycznych sytuacji, przekraczajacych wszelkie uprzednie wyobrażenia cztonków rodzin, rodzice i dzieci czesto byli zmuszeni zachowywać się w sposób, który w normalnych czasach bytby nie do pomyślenia. Takie momenty, opisane w licznych dziennikach, świadectwach i wspomnieniach, pozostawity nam ktopotliwe dziedzictwo pamięci, o którym nie da się tatwo zapomnieć - L. Langer, Scena pamięci..., s. 127.

53 Tamże, s. 139.

54 P. Czapliński, Zagtada i profanacje, „Teksty Drugie” 2009, nr 4, s. 199.

55 A. Spiegelman, Maus. Opowieść ocalatego, t. 1: Mój ojciec krwawi historią, przeł. P. Bikont, Kraków 2010, s. 105. 
zwarcie na wszystkich moich stykach... obciętaś mi końcówki nerwów... przepalitaś wszystkie moje przewody!... Zamordowataś mnie. Mamusiu, i zostawitaś tu, żeby jeszcze spadta na mnie kara!!! ${ }^{56}$. Marianne Hirsch, analizując Więźnia piekielnej planety, stwierdza: "Piekielna planeta" to zarówno Auschwitz, jak i psychika Arta. [...] "Piekielna planeta” pokazuje, w jakim stopniu te wojenne wspomnienia pozostaty bezpośrednio obecne w życiu Arta i jego rodziców, a także, jak bardzo nie zostaty oswojone. Pogrążony w żatobie Art nie pamięta jednak obozu koncentracyjnego, z którego pochodzi pasiak - jemu przypadta w udziale zapośredniczona przez wspomnienia rodziców postpamięć. Pozostaje więc więźniem swojego obozowego pasiaka i otoczonej czarnym marginesem przestrzeni swojej psychiki. Sugeruje się tu, że tworzenie Mausa stanowi próbę zarówno gtębszego wniknięcia w swoja postpamięć, jak znalezienia drogi odwrotu ${ }^{57}$.

Przemysław Czapliński, analizując dzieła należące do zespołu postpamięci, w tym także teksty literackie (m.in. Utwór o Matce i Ojczyźnie), stwierdzał, że są to prace mniej więcej o Holokauście ${ }^{58}$, że nie czynia z historycznego Holokaustu gtównego przedmiotu przedstawienia ${ }^{59}$, ze przywotuja Zagtadę w sposób oczywisty, a zarazem niejasny, że mówia o niej, ale nie tylko o niej i nie przede wszystkim o niej ${ }^{-60}$. Przywoływał wreszcie rozróżnienie Franka Ankersmita i powtarzał, że dzieła te nie są ekspresją doświadczenia Holokaustu, lecz ekspresja dotyczaca Holokaustu ${ }^{61}$.

Shoshana Ronen, sięgając, co prawda, po narracje pisarzy należących do „drugiego pokolenia" w sensie kulturowym i literackim, wnioskowała, iż w tekstach tych Szoa nie jest przedstawiona jako wydarzenie historyczne, ale raczej jako doświadczenie duszy, jako wewnętrzne piekto, mitologiczna konkretyzacja lęków ${ }^{62}$. Jak się zdaje, jej spostrzeżenia odnosić można do generacji (i narracji) dzieci ocalałych w ogóle.

Zaryzykować można stwierdzenie, że jeśli - jak chce Hirsch - rola Andzi w tej rodzinnej konstrukcji sprawia, że wspótpraca Arta $i$ Wtadka staje się procesem tego, co mę$s k i e^{63}$, to nieobecność ojca, jego odsunięcie, wreszcie to, że prawda, do której chcą dotrzeć córki ojców nie dotyczy, powoduje, że mamy w interesujących mnie tutaj narracjach do czynienia z tym, co kobiece, z narracją „obciążoną płciowo" ${ }^{64}$. Nawet jeśli bohaterki-autorki wypowiadają głośno brak ojca, to cała późniejsza walka, którą na kartach tych tekstów możemy obserwować, nie rozgrywa się o jego obecność, ale o to właśnie, co wyniknąć może wyłącznie z tej nieobecności, ze współobcowania dwóch kobiet - matki i córki. Ojciec albo jest postacią spoza tego doświadczenia, spoza żydowskości i Zagłady, albo nie funkcjonuje w życiu córki z innego powodu. $\mathrm{O}$ ile zatem

\footnotetext{
56 Tamże.

57 M. Hirsch, Żatoba i postpamięć, s. 269.

58 P. Czapliński, Zagtada..., s. 201.

59 Tamże, s. 203.

60 Tamże, s. 202.

61 Tamże.

62 S. Ronen, Od zmagań..., s. 87.

63 M. Hirsek, Źródta i postpamięć, s. 272.

64 Zob.: tamże.
} 
w Mausie współpraca ojca i syna prowadzić ma do zrekonstruowania głosu i losu matki, o tyle w Utworze o Matce i Ojczyźnie, Frascati, Wtoskich szpilkach i Rodzinnej historii lęku dochodzi do pewnego przesunięcia - nieobecność ojca pozwala matce i córce na zyskanie przestrzeni dialogu, przywrócenie im głosu, a na gruncie dzieła - wyeksponowanie kobiecej relacji. Idąc dalej za myślą Hirsch, stwierdzić można więc, że matka i córka współpracują jako para twórczych kobiet, zaś trudności, które budują ich relację, stuż jedynie wzmocnieniu tej więzi trzymajacej ich przy sobie i przy wspólnym przedsięwzięciu ${ }^{65}$. Ma zatem rację, ale i słuszną intuicję w odniesieniu do innych tego typu przypadków, Bożena Keff, gdy pisze w Utworze o Matce i Ojczyźnie: prosimy o zrozumienie, / Że ojca zostawiamy poza nawiasem tej tutaj historii, / Ale taki jest nasz przypadek (UoMiO, s. 68). Obecne na kartach interesujących mnie utworów wspomnienia o matkach stanowią, podobnie jak Więzień piekielnej planety w Mausie - pracę pamięci. To, czego dowiadujemy się o Zagładzie, jest natomiast „tworzeniem postpamięci”66.

\section{PODSUMOWANIE}

Teksty interesujące w kontekście niniejszych rozważań nie są opowieściami niedoszłych ofiar Zagłady. To zatem nie opowieści o samej Zagładzie, ale o życiu „po” - relacje obserwatorów, współuczestników życia „po Szoa”, i tak jak w przypadku relacji naocznych świadków Zagłady (nie-Żydów), mamy do czynienia z zapośredniczeniem ${ }^{67}$. Matki nie snują opowieści. Powiedzieć można, że nie są to narracje, które mają początek i koniec. To natomiast historie wyłuskane ze strzępków matczynych słów, krzyków, żalu, oparte na interpretacji gestów, dopowiedzeniach, wypełnianiu luk. W każdym z utworów Zagłada pojawia się w przebłyskach, mgnieniach. Rola córki polega na kolekcjonowaniu odłamków, na składaniu w całość tego, co rozproszone, wreszcie: na tworzeniu własnej opowieści o wojennym losie matki-Żydówki, własnej opowieści o Zagładzie. Matka Ewy Kuryluk pyta: Miliony spalono, ja ocalatam. Po co? (Fr., s. 146), i mówi: Wmawiatam sobie, ze przeżytam, żeby dać świadectwo. Ale prawda mnie przerosta [...] W rezultacie ocalatam, żeby zataić (Fr., s. 47). Potomkini rekonstruuje historię rodziny, wpisuje ją w historię Zagłady, ale i tworzy porządek opowieści, której nie usłyszała od rodziców, przede wszystkim zaś od matki. To pośrednio droga ku własnej tożsamości, której odkrywanie albo pozostaje w opozycji do ukrywania swego pochodzenia przez matki, albo w sytuacji, gdy niekończąca się opowieść matki „anihiluje”, wymaga wypracowania kontrnarracji, języka, który byłby odmienny od matczynego. W Utworze o Matce i Ojczyźnie na pierwszy sygnat skruchy ze strony Matki, pierwszy przejaw rozsądku i krytycyzmu, Córka odpowiada: „muszępowiedzieć, że cztowiekiem jesteśprzyzwoitym”. Wtaśnie w tym momencie wszystko, co sprawiato wrażenie retoryki przemocy stosowanej przez

65 Tamże, s. 273.

66 Tamże, s. 274.

67 Czy raczej: z zapośredniczoną opowieścią, opowieścią o cudzym doświadczeniu, opowieścią tego, kto zetkną się z Zagładą w sposób niebezpośredni. 
Matkę wobec Córki, nabiera charakteru historycznego świadectwa i Zagtada dochodzi do gtosu ${ }^{68}$. We wszystkich analizowanych w niniejszym szkicu utworach mamy zatem do czynienia ze skomplikowaną relacją dwójki kobiet, które prowadzą ze sobą złożony, trudny, czasami bolesny dialog. Wspólny pokój - wnętrze domu, przestrzeń rozmowy, daje rozmówczyniom niezbędny im czas na dotarcie do prawdy o nich samych. Ich zmaganie jest twórcze.

\section{BIBLIOGRAFIA}

Bielas K., Nielegalny plik, rozmowa z Bożeną Umińską-Keff, „Gazeta Wyborcza” 2008, 27 V, [online] http://wyborcza.pl/duzyformat/1,127291,5250183,Nielegalny_plik.html.

Brzóstowicz M., Wizerunek rodziny w polskiej prozie wspótczesnej, Poznań 1998, Biblioteka Literacka „Poznańskich Studiów Polonistycznych", t. 8.

Choduń A., Córka o matce, czyli „potwór” Bożeny Keff, „Tygiel Kultury” 2011, nr 7-9, [online] http://www.tygielkultury.eu/7_9_2011/aktual/30.htm.

Cuber M., Metonimie Zagtady. O polskiej prozie lat 1987-2012, Katowice 2012, Prace Naukowe Uniwersytetu Ślaskiego w Katowicach, $\mathrm{nr} 3027$.

Czapliński P., Mausoleum, „Tygodnik Powszechny” 2008, nr 37, [online] http://tygodnik.onet. $\mathrm{pl} /$ kultura/mausoleum/8fsvl.

Czapliński P., Wypowiadanie wojny. Literatura najnowsza wobec okresu 1939-1945, [w:] Wojna i postpamięć, red. Z. Majchrowski, W. Owczarski, Gdańsk 2011.

Czapliński P., Zagtada i profanacje, „Teksty Drugie” 2009, nr 4.

Czerska T., Historia rodziny - rodzina w historii, [w:] Prywatne/publiczne. Gatunki pisarstwa kobiecego, red. I. Iwasiów, Szczecin 2008, Rozprawy i Studia - Uniwersytet Szczeciński, t. 723.

Dąbrowska D., Udomowiony świat. O kobiecym doświadczaniu historii, Szczecin 2004, Rozprawy i Studia - Uniwersytet Szczecinski, t. 512.

Galant A., Zakochane bez pamięci. Szkic do wspótczesnych kobiecych „narracji rodzinnych”, [w:] Poetologie pamięci, red. D. Śnieżka, Szczecin 2011, Rozprawy i Studia - Uniwersytet Szczecinski, t. 806.

Halbwachs M., Zbiorowa pamięć rodziny, [w:] tenże, Spoteczne ramy pamięci, przeł. i wstęp M. Król, Warszawa 1969, Biblioteka Socjologiczna.

Hirsch M., The Generation of Postmemory. Writing and Visual Culture After the Holocaust, New York 2012, Gender and Culture.

Hirsch M., Żatoba i postpamięć, przeł. K. Bojarska, [w:] Teoria wiedzy o przesztości na tle wspótczesnej humanistyki, red. E. Domańska, Poznań 2010.

Janion M., Filipiak I., Zmagania z Matka i Ojczyzna, [w:] B. Keff, Utwór o Matce i Ojczyźnie, Kraków 2008.

Jarecka D., Ewa Kuryluk: każdy jest dla kogoś dobry, „Gazeta Wyborcza” 2010, 6 X, [online] http://wyborcza.pl/1,75475,7112897,Ewa_Kuryluk_Ktos_jest_dla_kogos_dobry.html.

68 P. Czapliński, Mausoleum. 
Karolak S., Zabójstwo dziecka w literaturze polskiej o Zagtadzie, [w:] Zabójstwo dziecka w literaturze i kulturze europejskiej, red. nauk. K. Ilski i in., Poznań 2014, Badania Interdyscyplinarne - Uniwersytet im. Adama Mickiewicza w Poznaniu, nr 36.

Karwowska B., Ciato. Seksualność. Obozy zagtady, Kraków 2009, Modernizm w Polsce, t. 28.

Keff B., Utwór o Matce i Ojczyźnie, Kraków 2008.

Kubisiowska K., Magdalena Tulli: Ludzik mi padt, więc gram następnym, „Gazeta Wyborcza” 2011, 30 X, [online] http://wyborcza.pl/duzyformat/1,127291,10548289,Magdalena_ Tulli_Ludzik_mi_padl_wiec_gram_nastepnym.html.

Kuryluk E., Frascati. Apoteoza topografii, Kraków 2009.

Langer L., Scena pamięci. Rodzice i dzieci w tekstach i świadectwach Holokaustu, przeł. J. Mikos, „Literatura na Świecie” 2004, nr 1/2.

Łysak T., Meandry ujawniania - póżne odkrycie tożsamości w „Rodzinnej historii lęku” Agaty Tuszyńskiej, [w:] Zagtada. Wspótczesne problemy rozumienia i przedstawiania, red. E. Domańska, P. Czapliński, Poznań 2009, Biblioteka Literacka „Poznańskich Studiów Polonistycznych", t. 56.

Nikliborc A., Uwięzione w KL Auschwitz-Birkenau. Traumatyczne doświadczenia kobiet odzwierciedlone w dokumentach osobistych, Kraków 2010.

Ostrowska J., Obca ofiara - figura prostytutki obozowej i jej wyparcie w dyskursie poholokaustowym, „uniGENDER” 2010, nr 1, [online] www.unigender.org/?page=biezacy\&issue= $04 \&$ article $=02$.

Prot-Klinger K., Wptyw traumy na relacje w rodzinie, [w:] taż, Życie po Zagtadzie. Skutki traumy u ocalatych z Holocaustu. Świadectwa z Polski i Rumunii, Warszawa 2009, Monografie Psychiatryczne, 9.

Ronen S., Od zmagań z bestia nazistowska w piwnicy do zmagań z ta bestia w nas samych, przeł. $\mathrm{z}$ ang. S. Obirek, przeł. z hebr. Michał Sobelman, [w:] Porzucić etyczna arogancje. Ku reinterpretacji podstawowych pojęć humanistyki w świetle wydarzenia Szoa, red. B.A. Polak, T. Polak, Poznań 2011.

Sobolewski T., Nike 2012. Magdalena Tulli: nie ma zmyślonych opowieści, „Gazeta Wyborcza” 2012, 15 IX, [online] http://wyborcza.pl/1,75475,12487543,Nike_2012_Magdalena_ Tulli_Nie_ma_zmyslonych_opowiesci.html.

Spiegelman A., Maus. Opowieść ocalatego, t. 1: Mój ojciec krwawi historią, przeł. P. Bikont. Kraków 2010.

Strzałka J., Sekrety rodzinne. Recenzja ksiązki: Ewa Kuryluk, „Frascati”, „Polityka” 2009, 13 X, [online] http://www.polityka.pl/tygodnikpolityka/kultura/ksiazki/304410,1,recenzja-ksiazki-ewa-kuryluk-frascati.read.

Stöcker-Sobelman J., Kobiety Holokaustu. Feministyczna perspektywa w badaniach nad Shoah. Kazus KL Auschwitz-Birkenau, Warszawa 2012.

Tulli M., Wtoskie szpilki, Warszawa 2011.

Tuszyńska A., Rodzinna historia lęku, Kraków 2005.

Ubertowska A., Archeologie pamięci. Wspótczesne kobiece narracje o wojnie, [w:] Wojna i postpamięć, red. Z. Majchrowski, W. Owczarski, Gdańsk 2011.

Ubertowska A., „Niewidzialne świadectwa”. Perspektywa feministyczna w badaniach nad literatura Holokaustu, „Teksty Drugie” 2009, nr 4. 
Wilk M., Życie jako dzieto sztuki, „Polityka” 2009, 13 X, [online] http://www.polityka.pl/tygodnikpolityka/kultura/304502,1,zycie-jako-dzielo-sztuki.read.

Winnicka E., Kangur w skórze stonia. Rozmowa z Ewa Kuryluk. O powojennym dzieciństwie, traumach, chorobie i wytchnieniu, które daje sztuka, „Polityka” 2010, 27 III, [online] http:// www.polityka.pl/tygodnikpolityka/kultura/1504420,1,rozmowa-z-ewa-kuryluk.read.

Wszystko o Matce-Żydówce. Wokót ksiązki Bożeny Keff „Utwór o Matce i Ojczyźnie”, [online] http://genderstudies.pl/index.php/aktualnosci/feminaria/wszystko-o-matce-zydowce-wokol-ksiazki-bozeny-keff-utwor-o-matce-i-ojczyznie-relacja.

Wysocki G., Magdalena Tulli, „Wtoskie szpilki”, dwutygodnik.com, [online] http://www.dwutygodnik.com/artykul/2862-magdalena-tulli-wloskie-szpilki.html.

Zaleski M., „Wtoskie szpilki” Magdalena Tulli, [online] http://www.instytutksiazki.pl/ksiazki-detal,literatura-polska,3169,wloskie-szpilki.html.

Dr Sylwia KAROLAK - literaturoznawczyni, adiunkt w Zakładzie Antropologii Literatury Uniwersytetu im. Adama Mickiewicza w Poznaniu. Interesuje się kulturą Żydów polskich, a także literaturą poświęconą Zagładzie. Ostatnio zajmuje się obecnością wątków postpamięciowych w literaturze polskiej, a także kreślonymi ręką kobiet utworami dotyczącymi II wojny światowej. Autorka książki Doświadczenie Zagtady w literaturze polskiej 1947-1991. Kanon, który nie powstat (2014). 